\title{
Federal Funding Insulated State Budgets From Increased Spending Related To Medicaid Expansion
}

\section{Citation}

Sommers, Benjamin D., and Jonathan Gruber. 2017. “Federal Funding Insulated State Budgets From Increased Spending Related To Medicaid Expansion." Health Affairs 36 (5) (April 12): 938944. doi:10.1377/hlthaff.2016.1666.

\section{Published Version}

10.1377/hlthaff.2016.1666

\section{Permanent link}

http://nrs.harvard.edu/urn-3:HUL.InstRepos:33332414

\section{Terms of Use}

This article was downloaded from Harvard University's DASH repository, and is made available under the terms and conditions applicable to Open Access Policy Articles, as set forth at http:// nrs.harvard.edu/urn-3:HUL.InstRepos:dash.current.terms-of-use\#OAP

\section{Share Your Story}

The Harvard community has made this article openly available.

Please share how this access benefits you. Submit a story.

\section{Accessibility}




\title{
State Budget Effects of the Affordable Care Act's Medicaid Expansion
}

\author{
Benjamin D. Sommers, MD, PhD \\ Jonathan Gruber, $\mathrm{PhD}$
}

\begin{abstract}
Affiliations: From the Department of Health Policy and Management, Harvard T.H. Chan School of Public Health, and the Department of Medicine, Brigham \& Women's Hospital (B.D.S.), and the Department of Economics at the Massachusetts Institute of Technology (J.G.).

Funding/Disclosures: Benjamin Sommers's work on this project was supported by the Agency for Healthcare Research and Quality (AHRQ; Grant No. K02HS021291). The views presented here are those of the authors and do not represent the views of AHRQ. The authors are grateful to Tiffany Li for her research assistance on this project.
\end{abstract}

\begin{abstract}
:
As states weigh whether to expand Medicaid under the Affordable Care Act (ACA) and Congress debates a potential repeal of the law and fundamental Medicaid reform, fiscal considerations loom large. The federal government paid for $100 \%$ of the costs for newly-eligible Medicaid enrollees from 2014-2016, with the state share rising to $10 \%$ by 2020 . But states continue to pay their traditional Medicaid share (roughly $25-50 \%$, depending on the state) for previously-eligible enrollees. We used 2010-2015 fiscal year data from the National Association of State Budget Officers and a difference-in-differences framework to assess the effects of the expansion's first two fiscal years. We find that the ACA's expansion led to an $11.7 \%$ increase in Medicaid spending, which was accompanied by a $12.2 \%$ increase in federal funding. There were no significant increases in state-funded spending due to expansion, nor any significant reductions in spending on education or other programs. Meanwhile, states' advanced budget projections were reasonably accurate in the aggregate, with no significant differences between the projected levels of federal, state, and Medicaid spending and the actual expenses as measured at fiscal year's end.
\end{abstract}

Keywords: Medicaid, State Issues, Health Spending, Health Reform

Word Count (including References): 3755

Version Date: February 2, 2017 


\section{INTRODUCTION}

Medicaid expansion under the Affordable Care Act (ACA) has been a subject of intense political debate and economic analysis. 31 states plus the District of Columbia have elected to expand coverage under the law, with generous terms of federal funding $-100 \%$ for newlyeligible adults through 2016 , eventually declining to $90 \%$ in the long-run. ${ }^{1}$ However, other aspects of the health reform law could increase state spending on Medicaid even during the period of $100 \%$ federal financing for the expansion population. Features of the ACA have increased enrollment among children and adults already eligible for Medicaid, ${ }^{2,3}$ and this socalled "woodwork effect" or "welcome mat effect" leaves states responsible for a larger share of costs based on their traditional federal match rate, which currently ranges from $50 \%$ to $74 \%$ depending on the state. This has raised concerns that expansion of Medicaid may actually be more costly to states than originally anticipated. ${ }^{4}$

There have also been doubts about whether inaccurate state projections for the costs of Medicaid expansion could lead to major budget shortfalls, ${ }^{5}$ which might force states to cut back spending in other areas including education and transportation. ${ }^{6}$ As Congress and a new administration consider repealing the ACA and dramatic changes to Medicaid funding, such as a block grant or per capita allotment system instead of the current match rate, ${ }^{7}$ understanding the state budget impact thus far of the Medicaid expansion has important implications.

Since its implementation, there have been several targeted analyses of state budgets impacts under the ACA's Medicaid expansion. One study analyzing budget reports in 11 expansion states demonstrated savings in state Medicaid spending, as some previously-eligible adults became eligible for the enhanced ACA match rate, while states simultaneously reduced their spending on programs for the uninsured. ${ }^{8}$ Other reports examining several expansion states 
found some increase in enrollment from the woodwork effect, with modest increases in state costs, but also offsetting savings from reduced spending on state programs for the uninsured and behavioral health. ${ }^{9,10}$ Several states have also published their own reports, with variations of these general findings. ${ }^{1}$ However, to our knowledge, there has been no systematic quantitative analysis of these budgetary effects across all states, particularly comparing the experiences of expansion versus non-expansion states.

The objective of our study was to analyze state budget reports from fiscal years 20102015 in order to assess the impacts of state Medicaid expansion decisions on total spending, Medicaid spending, spending on other categories, and the source of funds (federal vs. state). We also compared differences between states' budget projections at the outset of each fiscal year versus the year-end actual amounts to assess their accuracy.

\section{METHODS}

\section{Data}

Our primary data come from the annual State Expenditure Reports released by the National Association of State Budget Officers (NASBO). NASBO is a non-partisan independent professional organization whose membership is composed of heads of state finance departments, state chief budget officers, and their deputies. These reports, which were first issued in 1987, collects state-provided figures for fiscal-year spending and reports spending along two distinct dimensions - first, the category of services the funds were spent on, and second, the source (federal or state) of funds used for that spending. For clarify, we refer below to these two dimensions as the category and the source of spending. 
NASBO data incudes the following categories of spending: Medicaid, elementary/secondary education, higher education, public assistance, transportation, and "all other." The reports then describe the following sources of spending: federal funds, state general revenues, other state sources, and bonds.

Finally, each year's report includes actual spending figures for the prior fiscal year, as well as each state's projected budget figures for the upcoming fiscal year. Published information on actual spending is now current through the end of fiscal year $2015 .{ }^{11}$ Of note, in 46 states, the fiscal year begins on July 1, meaning that our data extends through mid-2015 for most states (i.e. 18 months into the ACA's Medicaid expansion that began January 2014). ${ }^{12}$

Secondary data used in our analysis include unemployment rates and per capita income from the Bureau of Labor Statistics, and information on Medicaid expansion status and eligibility criteria from previous research, the Kaiser Family Foundation, and the Centers for Medicare and Medicaid Services. $^{2,13-15}$

\section{Data Analysis}

Our analytical approach was a difference-in-differences model. In this approach, we compared changes before and after 2014 in Medicaid expansion states to the analogous changes occurring over time in non-expansion states. Each observation is at the state level, with one observation per fiscal year, yielding a sample of 300 state-year observations (Washington, DC is not included in the NASBO data). Each observation was given equal weight in the analysis; we did not weight by state size.

We have two sets of outcomes. First, we examined total spending and source of spending - federal, state, and bonds; in sensitivity analyses, we examined "state general revenue" and 
"other state funding" separately. Then, we examined categories of spending, including Medicaid and NASBO's five other categories as outlined above. For descriptive purposes, we present summary statistics and graphs using percentage of the total state budget and/or per capita spending, based on state population totals from the American Community Survey. But our primary regression models evaluating the expansion effects used the logarithm of spending to address the skewed distribution of the outcomes; this means our regression results provide estimates of the relative change in each outcome.

Our main model uses a simple difference-in-differences model, which controls directly for the year, state, annual state unemployment rate and per capita income. The variable of interest is an indicator variable equal to 1 for states that had expanded Medicaid under the ACA at some point during that fiscal year. For 19 expansion states, this was 2014, while New Hampshire, Indiana, and Pennsylvania did so during fiscal year 2015. States expanding after the end of the fiscal year on June 30, 2015, were treated as non-expansion states. We treated the five states that did partial expansions of Medicaid in 2011-2013 as not having fully expanded until 2014, since those early expansions were much smaller in scope than the full 2014 version. ${ }^{16}$

In an additional set of models, we tested whether the budget changes we detected were linked not only to the presence of Medicaid expansion but also to the size of that expansion. In this model, we replaced the binary indicator for "Medicaid expansion" with a measure of the estimated percentage of a standardized population of non-elderly individuals that would have become newly-eligible for Medicaid in each state. This measure is based on analysis from the American Community Survey and previously published research on the Medicaid expansion. ${ }^{2}$ This variable was equal to $0 \%$ in all non-expansion states and $0 \%$ in expansion states prior to 2014, and it ranged to a maximum of 19.7\% in Arkansas for 2014-2015. 
Lastly, we conducted an analysis in which we analyzed not only the actual spending data but also the projected spending amounts from the beginning of each fiscal year. In this analysis, each state-year combination is present twice - with an actual datapoint and a projected datapoint. We specified the model identically as above, but added an interaction term for each covariate with an indicator for projected data. This let us directly compare the anticipated budget impacts of Medicaid expansion vs. the actual budget impacts.

Data analysis was conducted using Stata 14.0, and difference-in-differences models used robust standard errors clustered at the state level.

\section{Limitations}

The NASBO state budget data are all voluntarily reported by states and do not undergo any official audit or independent review. Thus, they may be subject to reporting error, strategic response, or definitional differences across states. Nonetheless, the NASBO data are cited regularly by policymakers and independent analysts such as the Congressional Budget Office,

offering additional support for their validity. ${ }^{17,18}$ Moreover, our use of state fixed effects should minimize the bias from any stable differences in how states report their expenditures, and the use of log-models limits the influence of any outliers in the dataset. In our view, the NASBO dataset is a unique and timely source of information on state budgets, whose benefits outweigh these particular limitations.

The NASBO spending categories are also broad enough that they may obscure important policy-relevant offsets related to Medicaid expansion. Such possibilities include reduced spending for one category of eligibility in the program partially supplanted by the newly-eligible adult category, or offsets in specific state-funded services such as mental health. For those sorts 
of changes, more detailed analyses of individual state budgets of the kind discussed previously may be more appropriate. ${ }^{8,10}$

As with any difference-in-differences model, our approach assumes that trends in outcomes would have been similar - absent the Medicaid expansion - between our expansion and non-expansion states. One potential threat to this assumption is the sharp increase in federal funding to states under the American Recovery and Reinvestment Act ("the stimulus") in fiscal years 2009-2010, and subsequent decline in 2011. ${ }^{11}$ While this volatility may introduce additional imprecision into our estimates, stimulus money went to expansion and non-expansion states alike, which means that it is unlikely to bias our analysis. Furthermore, we directly tested whether spending trends by funding source and category were diverging based on expansion status prior to 2014, and the results of this analysis offer support for our general approach. However, it is still possible that other time-varying omitted variables could be affecting our results. We adjust for both state-year unemployment rates and per capita incomes to address one of the most likely potential threats to our model - namely, differential economic growth across states.

Finally, our results reflect the first two fiscal years of Medicaid expansion, which captures only the first 18 months of the policy. Previous research and government statistics indicate that Medicaid enrollment has continued to grow in late 2015 and $2016,{ }^{19,20}$ which means that our results likely underestimate the current budget implications of the expansion as we enter calendar year 2017. Moreover, the financing of the expansion changed as of 2017, with the state share for newly-eligible adults rising from $0 \%$ to $5 \%$ (and ultimately to $10 \%$ by 2020 , if there is no legislative change before then). Future research will be necessary to assess these budget effects as state Medicaid spending increases. 


\section{RESULTS}

Exhibit 1 presents summary statistics for state spending in the pre-expansion period (2010-2013), split into expansions vs. non-expansion states. Patterns of funding sources and categories of spending were similar in expansion and non-expansion states. State general revenues accounted for $36-38 \%$ of spending, other state sources another $28-30 \%$, and federal sources 35\% in non-expansion vs. 30\% in expansion states. Medicaid was the largest category of overall spending (which includes matching federal funds), at approximately $22 \%$ in both groups of states. K-12 education and higher education were the second and third largest categories, totaling to approximately $30 \%$ overall. Transportation spending was $8-9 \%$, while public assistance and corrections each accounted for less than 3\% of state spending.

Exhibit 2 presents unadjusted levels of per capita spending for the three largest categories of spending - Medicaid, education (combining K-12 and higher education), and transportation. Before 2014, the trends for Medicaid and education were quite similar for expansion and nonexpansion states, offering support for the difference-in-differences approach. We formally test these trends in growth in Appendix Exhibit A1, described at more length below. ${ }^{21}$ Spending for Medicaid increased substantially in expansion states starting in 2014, with no obvious differential changes in educational spending. Transportation spending in expansion states was slightly smaller than in non-expansion states prior to 2014, but grew and surpassed nonexpansion states by 2015 .

Exhibit 3 presents our regression results for the Medicaid expansion's impact on source of spending and category of spending. The first set of columns shows the simple difference-indifferences estimate for expansion vs. non-expansion. Medicaid expansion was associated with a 
$5.8 \%$ increase in total spending $(\mathrm{p}=0.002)$ and a $12.2 \%$ increase in spending using federal funds $(\mathrm{p}=0.006)$. We did not detect any significant change in spending using state funds $(2.4 \%$, $\mathrm{p}=0.24)$. In terms of the category of spending, we found that expansion produced a large increase in Medicaid expenditures as expected $(11.7 \%, \mathrm{p}<.001)$. We found no significant reductions in spending on other categories, and some suggestive evidence of increased spending after expansion on transportation $(8.0 \%, \mathrm{p}=0.062)$ and "other" $(10.1 \%, \mathrm{p}=0.057)$.

In the second set of columns in Exhibit 3, we assessed the size of each state's Medicaid expansion. We found that the increase in total spending, federal spending, and Medicaid spending tracked closely with the percent of each state's population that became newly eligible. These estimates can be interpreted as the change in spending for each additional $1 \%$ of the nonelderly population becoming newly-eligible for Medicaid. For instance, we find that each additional $1 \%$ newly-eligible in an expansion state was linked to $0.86 \%$ growth in state Medicaid spending. Using this more refined measure of expansion, we still do not see any significant change in spending using state funds $(0.17 \%, \mathrm{p}=0.32)$ nor any non-Medicaid categories. However, using this measure, we no longer find any significant increases in spending on transportation or "other."

Exhibit 4 compares our main estimates for Medicaid expansion vs. non-expansion, using the projected budget data versus the actual results; this analysis excludes 5 states that submitted the same totals for both data points (projected and actual) in either 2014 or 2015. The last column shows whether the projected effects at the beginning of the fiscal year and actual effects at the end of the year differed significantly. In all cases, we find that they did not. Differences were modest for nearly all measures (other than bonds, which were highly imprecise) and none of the differences were statistically significant. The difference in projected vs. actual impact of 
expansion was $0.8 \%$ for total spending $(\mathrm{p}=0.64),-3.5 \%$ (i.e. lower than projected, $\mathrm{p}=0.42$ ) for federal funds, $+2.6 \%$ for state funds $(\mathrm{p}=0.30)$, and $+2.9 \%(\mathrm{p}=0.31)$ for Medicaid spending.

Appendix Exhibit A1 presents an analysis of the pre-2014 trends in our spending outcomes. $^{21}$ We find no evidence of divergent trends based on state expansion status in our key spending measures prior to 2014. For instance, differences in total spending per year was just $0.3 \%$ per year in expansion states vs. non-expansion, a non-significant result $(\mathrm{p}=0.74)$. Pre-2014 differential changes in state and federal funding levels, as well as Medicaid spending, were similarly small and non-significant. We did find that spending on higher education was declining in expansion states relative to non-expansion states prior to $2014(-7.7 \%$ per year, $\mathrm{p}=0.002$ ); this trend would bias us towards finding a spurious reduction in spending on higher education after Medicaid expansion, and while our point estimate for higher education (Exhibit 3) is consistent with this trend, it was not statistically significant.

\section{DISCUSSION}

In this study, we analyzed official state budget reports from all 50 states for fiscal years 2010-2015 (which extends roughly 1.5 years into the ACA's expansion). As expected, we found that expansion led to significant increases in spending on Medicaid $-11.7 \%$ on average - but this occurred almost entirely based on increased federal spending. We detected no significant changes in spending from state sources, and no resulting changes in spending on education, transportation, or other state programs. Thus, while some have voiced concerns that Medicaid expansion could lead to increased state spending due to the woodwork effect and/or squeeze out competing spending for other priorities such as education, we find that neither of these concerns have yet materialized. 
Given evidence that Medicaid enrollment among previously-eligible individuals has increased under the ACA, how can we reconcile this fact with our finding of no increase in state spending? Our study design focuses on the impact of state Medicaid expansion decisions, rather than the ACA as a whole. While the woodwork effect under the ACA likely has increased state spending on Medicaid, our results suggest that whether or not a state has chosen to expand Medicaid has little impact on this phenomenon. This is consistent with other research that demonstrates a prominent woodwork effect in both expansion and non-expansion states. ${ }^{2}$ In addition, the fact that many of the previously-eligible individuals are likely to be children means that the overall budget implications are smaller, given that children are relatively inexpensive to insure. $^{3}$

While Medicaid spending increased substantially in expansion states as expected, we did not see any spillover effects to suggest that Medicaid crowded out other state priorities in the budget. If anything, we see suggestive but inconsistent evidence that Medicaid expansion and the major increase in federal funds may have allowed participating states to address other priorities, such as transportation spending (which increased 8\%) and other spending (which increased 10\%). However, these changes did not track closely with the size of a state's Medicaid expansion, making it unclear how directly they were related to that policy.

Finally, we find that state budget projections were - in the aggregate - reasonably accurate at assessing likely changes in spending due to the Medicaid expansion. This is in contradiction to some of the concerns about potentially large cost overruns in the program associated with the $\mathrm{ACA} ;{ }^{4}$ however, while in the aggregate the projections performed well, individual states' experiences of course varied widely. To that end, in our data, the state-level 
error rate on 2013 vs. 2015 Medicaid spending in projections vs. actual levels ranged from -26\% to $+46 \%$.

\section{Conclusion}

We find that the first two fiscal years of the ACA's Medicaid expansion led to large increases in federal spending on Medicaid, but states that expanded did not experience any significant added increase in state-funded expenditures, and there is no evidence that expansion crowded out other state priorities. This is consistent with the intent of the ACA's generous federal funding of the Medicaid expansion, and indicates that enrollment of previously-eligible individuals - for whom states only receive partial federal reimbursement - did not lead to higher state spending in expansion states compared to non-expansion states.

As state and federal policymakers consider the future of the ACA and the potential restructuring of Medicaid financing more broadly, our findings indicate that some of the original state budget concerns voiced regarding Medicaid expansion have not yet materialized. But given the heavy reliance of the expansion on federal funding, either a repeal of the ACA or a substantial reduction in federal Medicaid support to states (as being currently debated ${ }^{22}$ ) would undoubtedly undermine the coverage gains achieved to date and would likely put at risk other state budgetary priorities. 


\section{References}

1. Antonisse L, Garfield R, Rudowitz R, Artiga S. The Effects of Medicaid Expansion under the ACA: Findings from a Literature Review. Washington, DC: Kaiser Family Foundation; 2016.

2. Frean M, Gruber J, Sommers BD. Premium Subsidies, the Mandate, and Medicaid Expansion: Coverage Effects of the Affordable Care Act. Cambridge, MA: National Bureau of Economic Research; 2016.

3. Kenney GM, Haley J, Pan C, Lynch V, Buettgens M. Children's Coverage Climb Continues: Uninsurance and Medicaid/CHIP Eligibility and Participation Under the ACA: Urban Institute / Robert Wood Johnson Foundation; 2016.

4. Alonso-Zaldivar R. Medicaid Surge Triggers Cost Concerns for States. Associated Press 2014 May 26.

5. Sommers BD, Swartz K, Epstein A. Policy makers should prepare for major uncertainties in medicaid enrollment, costs, and needs for physicians under health reform. Health Aff (Millwood) 2011;30:2186-93.

6. Miller D. Growing Medicaid Budgets Squeezing Out Other Priorities. Lexington, KY: Council of State Governments; 2016.

7. Ryan P. A Better Way: Health Care. Washington, DC: Office of the Speaker of the House; 2016.

8. Bachrach D, Boozang P, Herring A, Reyneri DG. States Expanding Medicaid See Significant Budget Savings and Revenue Gains. Princeton, NJ: Robert Wood Johnson Foundation; 2016.

9. Dorn S, Francis N, Snyder L, Rudowitz R. The Effects of the Medicaid Expansion on State Budgets: Kaiser Family Foundation; 2015.

10. Ayanian JZ, Ehrlich GM, Grimes DR, Levy H. Economic Effects of Medicaid Expansion in Michigan. N Engl J Med 2017.

11. State Expenditure Report: Examining Fiscal 2014-2016 State Spending. Washington, DC: National Association of State Budget Officers; 2016.

12. In New York, the fiscal year begins on April 1; in Texas, July 1; and in Alabama and Michigan, October 1.

13. Heberlein M, Brooks T, Aiker J, Artiga S, Stephens J. Getting into Gear for 2014: Findings from a 50-State Survey of Eligibility, Enrollment, Renewal, and Cost-Sharing Policies in Medicaid and CHIP, 2012-2013. Washington, D.C.: Kaiser Family Foundation; 2013.

14. CMS. State Medicaid and CHIP Income Eligibility Standards. Baltimore, MD: Centers for Medicaid \& CHIP Services; 2014.

15. Status of State Action on the Medicaid Expansion Decision. Kaiser Family Foundation, 2015. at http://kff.org/health-reform/state-indicator/state-activity-around-expanding-medicaidunder-the-affordable-care-act/.)

16. Sommers BD, Arntson E, Kenney GM, Epstein AM. Lessons from Early Medicaid Expansions under Health Reform: Interviews with Medicaid Official. Medicare Medicaid Res Rev 2013;3:E1-E23.

17. The Budget and Economic Outlook: Fiscal Years 2005 to 2014 Washington, D.C.: Congressional Budget Office; 2005. 
18. The Impact of Unauthorized Immigrants on the Budgets of State and Local Governments. Washington, D.C.: Congressional Budget Office; 2007.

19. Medicaid \& CHIP: July and August 2016 Monthly Enrollment, Updated October 2016. Centers for Medicaid \& CHIP Services, 2016.

20. Sommers BD, Blendon RJ, Orav EJ, Epstein AM. Changes in Utilization and Health Among Low-Income Adults After Medicaid Expansion or Expanded Private Insurance. JAMA Intern Med 2016.

21. To access the Appendix, click on the Appendix link in the box to the right of the article online.

22. Chatterjee P, Sommers BD. JAMA Forum: The Economics of Medicaid Reform and Block Grants. JAMA 2017. 


\section{EXHIBIT LIST}

\section{Exhibit 1 (Table)}

Name: State Budget Sources and Categories of Spending, pre-ACA (Fiscal Years 2010-2013), By Medicaid Expansion Status

Source: Authors' analysis of State Expenditure Reports from the National Association of State Budget Officers.

\section{Exhibit 2 (Figure)}

Name: State Per Capita Spending for Major Categories of Expenditure (Fiscal Years 20102015), by Medicaid Expansion Status

Source: Authors' analysis of State Expenditure Reports from the National Association of State Budget Officers, combined with information on each state's annual population from the American Community Survey.

Notes: All outcomes are measured in nominal dollars per capita.

\section{Exhibit 3 (Table)}

Name: Changes in State Spending Associated with the Affordable Care Act's Medicaid Expansion (Fiscal Years 2010-2015)

Source: Authors' analysis of State Expenditure Reports from the National Association of State Budget Officers.

Notes: All models adjust for state annual per capita income and unemployment rate, as well as year and state, and use $\ln$ (spending) as the outcome. Robust standard errors were clustered by state.

"Medicaid Expansion Effect" reports the simple difference-in-differences estimate for the impact of Medicaid expansion vs. non-expansion. "\% Newly-Eligible Effect" reports the change in spending in each outcome as a function of the percentage of the non-elderly population that became newly-eligible for Medicaid under the ACA - see Methods for further details. N=300 state-year observations.

\section{Exhibit 4 (Table)}

Name: Comparing Projected vs. Actual State Spending Changes Associated with the Affordable Care Act's Medicaid Expansion (Fiscal Years 2010-2015)

Source: Authors' analysis of State Expenditure Reports from the National Association of State Budget Officers.

Notes: All models adjust for state annual per capita income and unemployment rate, as well as year and state, and use $\ln$ (spending) as the outcome. Robust standard errors were clustered by state. Difference is the absolute difference between the two estimates, and the p-value tested whether the projected and actual spending estimates differed significantly from one another. $\mathrm{N}=540$ state-year observations with one projected and one actual estimate per state-year combination, excluding the 5 states that did not report separate estimates for projected vs. actual spending. 


\section{Exhibit 1: State Budget Sources and Categories of Spending, pre-ACA (Fiscal Years 2010-2013), By Medicaid Expansion Status}

\begin{tabular}{|l|l|l|}
\hline Source of Spending & Non-Expansion States & Expansion States \\
\hline State General Revenue & $36.1 \%$ & $37.9 \%$ \\
\hline Federal & $34.6 \%$ & $29.9 \%$ \\
\hline Other State Sources & $28.0 \%$ & $29.9 \%$ \\
\hline Bonds & $1.3 \%$ & $2.3 \%$ \\
\hline & & \\
\hline Category of Spending & Non-Expansion States & Expansion States \\
\hline Medicaid & $21.8 \%$ & $22.0 \%$ \\
\hline K-12 Education & $18.7 \%$ & $20.0 \%$ \\
\hline Higher Education & $13.3 \%$ & $10.4 \%$ \\
\hline Transportation & $9.0 \%$ & $8.1 \%$ \\
\hline Corrections & $2.9 \%$ & $2.8 \%$ \\
\hline Public Assistance & $0.8 \%$ & $1.4 \%$ \\
\hline Other & $33.6 \%$ & $35.3 \%$ \\
\hline
\end{tabular}

Source: Authors' analysis of State Expenditure Reports from the National Association of State Budget Officers. 


\section{Exhibit 2: State Per Capita Spending for Major Categories of Expenditure (Fiscal Years 2010-2015), by Medicaid Expansion Status}

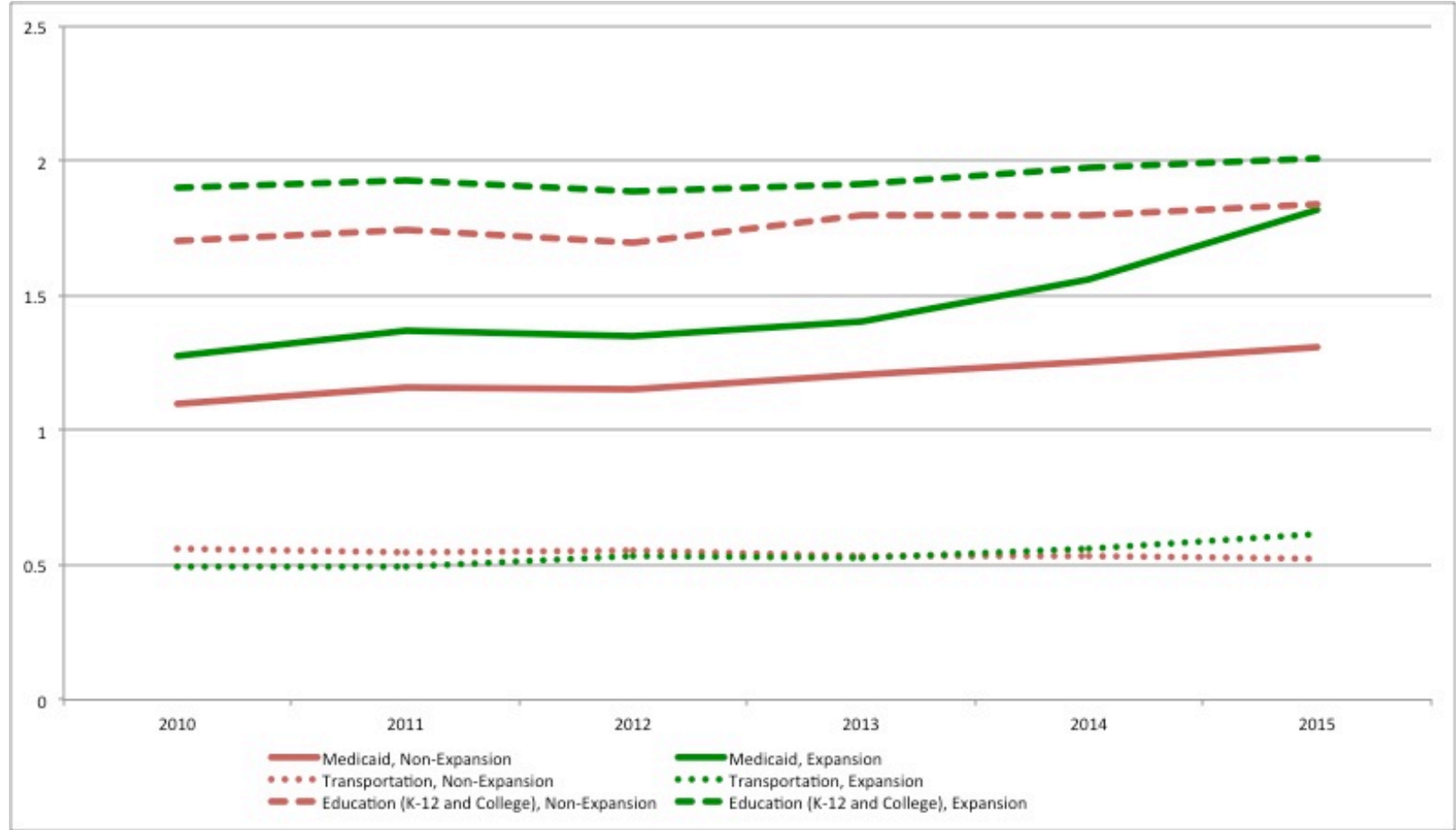

Source: Authors' analysis of State Expenditure Reports from the National Association of State Budget Officers, combined with information on each state's annual population from the American Community Survey.

Notes: All outcomes are measured in nominal dollars per capita. 


\section{Exhibit 3: Changes in State Spending Associated with the Affordable Care Act's Medicaid Expansion (Fiscal Years 2010-2015)}

\begin{tabular}{|c|c|c|c|c|}
\hline \multirow[t]{2}{*}{ OUTCOME } & \multicolumn{2}{|c|}{$\begin{array}{c}\text { MEDICAID EXPANSION } \\
\text { EFFECT }\end{array}$} & \multicolumn{2}{|c|}{$\begin{array}{c}\text { \% NEWLY-ELIGIBLE } \\
\text { EFFECT }\end{array}$} \\
\hline & $\begin{array}{c}\text { Percent } \\
\text { Change from } \\
\text { Expansion }\end{array}$ & p-value & $\begin{array}{c}\text { Change per 1\% } \\
\text { Newly-Medicaid } \\
\text { Eligible }\end{array}$ & p-value \\
\hline Total Spending & $5.8 \%$ & .002 & $0.32 \%$ & .048 \\
\hline \multicolumn{5}{|l|}{ Source of Funds } \\
\hline Federal Funds & $12.2 \%$ & .006 & $0.51 \%$ & .016 \\
\hline Spending from Bonds & $34.9 \%$ & .21 & $1.12 \%$ & .54 \\
\hline State Funds & $2.4 \%$ & .24 & $0.17 \%$ & .32 \\
\hline --State General Revenue & $2.9 \%$ & .35 & $-0.04 \%$ & .81 \\
\hline --Other State Funds & $3.1 \%$ & .54 & $0.39 \%$ & .28 \\
\hline \multicolumn{5}{|l|}{ Category of Spending } \\
\hline Medicaid & $11.7 \%$ & $<0.001$ & $0.86 \%$ & $<0.001$ \\
\hline K-12 Education & $-0.9 \%$ & .76 & $-0.08 \%$ & .70 \\
\hline Higher Education & $-5.0 \%$ & .25 & $-0.66 \%$ & .15 \\
\hline Transportation & $8.0 \%$ & .062 & $0.42 \%$ & .20 \\
\hline Corrections & $-0.4 \%$ & .88 & $-0.17 \%$ & .35 \\
\hline Public Assistance & $3.6 \%$ & .60 & $-0.21 \%$ & .67 \\
\hline Other & $10.1 \%$ & .057 & $0.62 \%$ & .13 \\
\hline
\end{tabular}

Source: Authors' analysis of State Expenditure Reports from the National Association of State Budget Officers. Notes: All models adjust for state annual per capita income and unemployment rate, as well as year and state, and use $\ln$ (spending) as the outcome. Robust standard errors were clustered by state.

"Medicaid Expansion Effect" reports the simple difference-in-differences estimate for the impact of Medicaid expansion vs. non-expansion. "\% Newly-Eligible Effect" reports the change in spending in each outcome as a function of the percentage of the non-elderly population that became newly-eligible for Medicaid under the ACA see Methods for further details. N=300 state-year observations. 


\section{Exhibit 4: Comparing Projected vs. Actual State Spending Changes Associated with the Affordable Care Act's Medicaid Expansion (Fiscal Years 2010-2015)}

\begin{tabular}{|c|c|c|c|c|}
\hline \multirow[t]{2}{*}{ OUTCOME } & \multicolumn{2}{|c|}{$\begin{array}{c}\text { PERCENT CHANGE FROM } \\
\text { EXPANSION }\end{array}$} & \multirow[t]{2}{*}{$\begin{array}{c}\text { Difference } \\
\text { (Actual - Projected) }\end{array}$} & \multirow[t]{2}{*}{$\begin{array}{l}\text { p-value for } \\
\text { Difference }\end{array}$} \\
\hline & $\begin{array}{l}\text { Projected } \\
\text { Spending }\end{array}$ & $\begin{array}{l}\text { Actual } \\
\text { Spending }\end{array}$ & & \\
\hline Total Spending & $6.1 \%$ & $6.9 \%$ & $0.8 \%$ & 0.64 \\
\hline \multicolumn{5}{|l|}{ Source of Funds } \\
\hline Federal Funds & $17.0 \%$ & $13.5 \%$ & $-3.5 \%$ & 0.42 \\
\hline Spending from Bonds & $0.1 \%$ & $31.8 \%$ & $31.7 \%$ & 0.18 \\
\hline State Funds & $1.0 \%$ & $3.6 \%$ & $2.6 \%$ & 0.30 \\
\hline --State General Revenue & $3.3 \%$ & $3.5 \%$ & $0.2 \%$ & 0.90 \\
\hline --Other State Funds & $0.5 \%$ & $4.3 \%$ & $3.8 \%$ & 0.43 \\
\hline \multicolumn{5}{|l|}{ Category of Spending } \\
\hline Medicaid & $9.7 \%$ & $12.6 \%$ & $2.9 \%$ & 0.31 \\
\hline K-12 Education & $-1.0 \%$ & $-1.0 \%$ & $0.0 \%$ & 0.98 \\
\hline Higher Education & $-10.1 \%$ & $-5.1 \%$ & $5.0 \%$ & 0.15 \\
\hline Transportation & $12.3 \%$ & $9.4 \%$ & $-2.9 \%$ & 0.34 \\
\hline Corrections & $1.1 \%$ & $-0.2 \%$ & $-1.3 \%$ & 0.75 \\
\hline Public Assistance & $2.5 \%$ & $3.8 \%$ & $1.3 \%$ & 0.93 \\
\hline Other & $11.3 \%$ & $11.3 \%$ & $0.0 \%$ & 0.99 \\
\hline
\end{tabular}

Source: Authors' analysis of State Expenditure Reports from the National Association of State Budget Officers. Notes: All models adjust for state annual per capita income and unemployment rate, as well as year and state, and use $\ln$ (spending) as the outcome. Robust standard errors were clustered by state. Difference is the absolute difference between the two estimates, and the p-value tested whether the projected and actual spending estimates differed significantly from one another. $\mathrm{N}=540$ state-year observations with one projected and one actual estimate per state-year combination, excluding the 5 states that did not report separate estimates for projected vs. actual spending. 


\section{Appendix Exhibit A1: Testing for Parallel Trends in Outcomes Between Expansion and Non-expansion States, Prior to the Medicaid Expansion (Fiscal Years 2010-2013)}

\begin{tabular}{|l|c|c|c|c|}
\hline OUTCOME & $\begin{array}{c}\text { Time Trend } \\
\text { Ever-Expand }\end{array}$ & $\begin{array}{c}\text { 95\% CI, } \\
\text { Lower Bound }\end{array}$ & $\begin{array}{c}\text { 95\% CI, } \\
\text { Upper Bound }\end{array}$ & p-value \\
\hline Total Spending & $0.3 \%$ & $-1.3 \%$ & $1.8 \%$ & .74 \\
\hline & & & & \\
\hline Source of Funds & & & & .7 \\
\hline Federal Funds & $-0.4 \%$ & $-2.7 \%$ & $31.3 \%$ & .74 \\
\hline Spending from Bonds & $4.5 \%$ & $-22.3 \%$ & $1.6 \%$ & .8 \\
\hline State Funds & $-0.2 \%$ & $-2.1 \%$ & $2.0 \%$ & .9 \\
\hline --State General Revenue & $0.1 \%$ & $-1.8 \%$ & $3.9 \%$ & .7 \\
\hline --Other State Funds & $0.6 \%$ & $-2.6 \%$ & & \\
\hline & & & $2.0 \%$ & .91 \\
\hline Category of Spending & & & $2.9 \%$ & .87 \\
\hline Medicaid & $-0.1 \%$ & $-2.2 \%$ & $-2.9 \%$ & .002 \\
\hline K-12 Education & $-0.3 \%$ & $-3.5 \%$ & $5.3 \%$ & .69 \\
\hline Higher Education & $-7.7 \%$ & $-12.5 \%$ & $1.9 \%$ & .18 \\
\hline Transportation & $2.5 \%$ & $-0.4 \%$ & $11.5 \%$ & .29 \\
\hline Corrections & $-0.5 \%$ & $-2.9 \%$ & $5.9 \%$ & \\
\hline Public Assistance & $4.7 \%$ & $-2.2 \%$ & & \\
\hline Other & $2.0 \%$ & $-1.8 \%$ & & \\
\hline
\end{tabular}

Source: Authors' analysis of State Expenditure Reports from the National Association of State Budget Officers. Notes: All models adjust for state annual per capita income and unemployment rate, as well as year and state, and use $\ln$ (spending) as the outcome. The coefficient of interest was a linear time trend interacted with "Ever Expand," which was equal to 1 for any state expanding Medicaid prior to the end of fiscal year 2015, and 0 otherwise.

$\mathrm{N}=200$ state-year observations 